\title{
THE POLISH COURT BANNER IN THE MOLDAVIAN EXPEDITION IN 1497
}

\begin{abstract}
The paper discusses the expedition of the Kingdom of Poland to Moldavia in 1497. The army of 50,000 included a detachment of courtiers (curienses) who were organised as the so-called court banner. It was a kind of royal guard of up to $2000 \mathrm{men}$. The army, led by the Polish king John I Albert, set off at the beginning of June from Lviv, and on 24 September the troops began a siege of Suceava, the capital of Moldavia. A well-fortified city was not captured and on 19 October the siege ended. During the retreat, on 26 October the Polish troops were attacked by the Moldavians and their allies in the Cosmin Forest in Bucovina (present-day Ukraine). In the clash, the court banner played an important role, by saving the knights of the general levy from a complete defeat. In the Central Archives of Historical Records in Warsaw there are registers of armaments lost in this battle by the curienses. The paper discusses the armaments of members of the court detachment and losses they suffered during the battle.
\end{abstract}

Keywords: Battle in the Cosmin Forest, John I Albert (Jan Olbracht), Kingdom of Poland, Moldavia, war, $15^{\text {th }}$ century

A lot has been said on the reasons for the expedition to Moldavia in 1497. The debate mainly concerns the aims of the campaign - whether it was the overthrow of the Moldavian prince (hospodar) Stephen and replacing him with Sigismund Jagiellon, or recapture of Kiliya ${ }^{1}$ and Bilhorod ${ }^{2}$ from the Turks. Both cities that belonged to Moldavia were taken over by the Ottoman Empire in 1484. Therefore, the Turks strengthened their position in the Black Sea region and took control over the trade on the Rivers Dnieper and Dniester. In this way Moldavia lost not only a part of its own territory but also important sources of income. After the attack of the Turks, Stephen turned to Hungary and Poland for help, as both countries claimed their rights for suzerainty over Moldavia. Mathias Corvinus, involved into a war in Austria, issued a protest to the sultan, accusing him of violating the territory of the Hungarian vassal. The country which was more profoundly involved into Moldavian affairs was Poland. Stephen, endangered by a loss of the throne to Peter Hronoda, paid homage to Casimir IV Jagiellon, King of Poland on 16 September 1485. Thanks to this, he received reinforcements of 3000 Polish soldiers, who helped in the war against Horonda.

* University of Łódź, tadeuszg@uni.lodz.pl

1 Today a town in the Odessa province of southwestern Ukraine.

2 Bilhorod-Dnistrovskyi (formerly known as Akkerman = White Castle) today in the territory of Ukraine, in the Odessa province.
However, the forces were insufficient to take back Kiliya and Bilhorod. The next attempt at regaining control over the ports in 1497 was undertaken by John I Albert (Jan Olbracht), King of Poland, son of Casimir IV Jagiellon. However, in order to achieve this objective, it was necessary to subjugate Moldavia ${ }^{3}$.

Preparations for the expedition started already in 1496 but entered a decisive phase in the spring of 1497. In March, the king was in Nowy Korczyn where he ordered that the general levy should assemble in Ruthenia on 21 May. However, the mobilisation proceeded with a delay, so it was only at the end of June that knights from Lesser Poland, Ruthenia and Podolia started gathering in camps around Lviv. After the king had made an inspection of the troops, the army moved from Lviv east, in the direction of Gologory, where they camped on 27 June. The fact that such a direction of the march was taken means that previous plans were modified and that it was intended to march to Halich. A bridge was constructed near this town in order to facilitate the army's crossing of the Dniester. From the vicinity of Gologory the army marched through Dunajów, Złotniki to reach Mogilnica on 18 July. There the king ordered a longer stop, because the general levy from Greater Poland who were marching separately were only in Busko. Pressed by John I Albert, Greater Poland's

3 Czamańska 1996, 171-175; Smołucha 1997, 413-421; Smołucha 1999, 59-60. 
troops accelerated the pace of their march. Going through Gliniany and Chernivtsi, they arrived in Mogilnica on 25 July. There, they joined the rest of the army. Knights from Greater Poland were accompanied by mercenary soldiers. The king again inspected the state of his army. Next, the troops set off south and on 12 August they crossed the River Dniester in the vicinity of Chervonohorod. Then, the army marched from Horodenka (14 August) toward Kocman. There, Stephen's deputies arrived and informed John I Albert that the hospodar did not want the Polish troops to pass through Moldavia. The king, irritated by this, ordered the imprisonment of the deputies, which meant an open conflict with the hospodar. From that time, Stephen's troops commenced to attack the Poles, making use of hitand-run tactics. During the meeting held in the Polish camp it was decided to march to Chernivtsi and continue along the left bank of the River Prut, toward Kiliya. At the same time, after the advice of Jan Trnka, one of the commanders, it was decided to capture Khotyn on the River Dniester ${ }^{4}$. This task was entrusted to the general levy from Greater Poland. However, after their arrival, their commander Jan Karnkowski decided that there was no way they could take the castle of Khotyn fast enough. It was therefore decided to turn back to the main forces. At that time the main part of the army already reached Hadir on the River Prut. Due to the failed attempt at occupying Khotyn and continuous attacks of Moldavian cavalry, it turned impossible to continue the march toward the Black Sea ports, as it could easily lead to the army being cut off from the supply base. It was therefore decided to head toward Suceava, the capital of Moldavia. If captured, it could become a base for further actions in the south against Stephen the Great. Furthermore, Stephen's position would certainly be weakened if the Polish troops were able to take his capital. After a decision to implement this concept had been made, John I Albert's troops crossed the River Prut on 11-12 September and headed southwest. On 18-20 September the army crossed the River Seret and captured a town of the same name 5 . Then, it came to a clash with the Tartars. The skirmish ended successfully for the Poles who chased after the fleeing enemy. The road to Suceava was open. John Albert's army reached the walls of the Moldavian capital on September $24^{6}$.

The army which stood at Suceava consisted mainly of the general levy from Lesser Poland, Ruthenia, Podolia, and Greater Poland, infantry and cavalry mercenary troops (1000 horsemen, and 1900 infantrymen), as well as the auxiliary detachment of the Teutonic Order (200-400 people $)^{7}$. The court banner went to Moldavia along with

4 Khotyn in present-day Ukraine.

5 Plewczyński 2002, 250-251.

6 Papée 1999, 134-141.

From Königsberg (now Kaliningrad in Russia) a detachment of 400 men (cavalry and infantry) set off on 1 June. Near Halych it turned out that the state of health of Grand Master the army. Its size is not precisely known, and it is estimated that up to 2000 courtiers participated in the expedition. The chronicler Marcin Kromer recorded that the king had up to 80,000 armed men in his army, not counting cooks and coachmen, who accounted for half of this number, and there were nearly 30,000 carts $^{8}$. Interestingly, John Albert's forces were estimated in one of the Turkish chronicles more modestly, at 60-70,000 men'. In a Hungarian report a number of 50,000 is given. This estimation is accepted in the most recent literature ${ }^{10}$. Regardless of conclusions concerning the numbers of John Albert's troops, all researchers agree that never before Poland sent such a large army into this area. This is confirmed by the opinion of Polish captains (campiductores) who were believed to say that although they had already served in a number of armies, they had never seen such an enormous one ${ }^{11}$.

The chief commander of this army was King John I Albert. The 37-year-old ruler had military experience gained during his father's life, commanding a military defending the south-eastern part of the Kingdom of Poland against Tatar invasions. In the years 1490-1492 he led an army in order to take over Hungary. Therefore, the expedition to Moldavia was not the first military operation he led. It should be noted, however, that he had never commanded such a large army before. Direct command over mercenaries was taken by Jan Trnka of Raciborzany, under whom Stanisław of Chodecz served. The latter was a, commander of troops guarding the south-eastern borders of the Kingdom. The court banner was commanded by the Court Marshall Rafał Leszczyński ${ }^{12}$. Among the men in the entourage of the king there were many experienced knights.

The Polish army at Suceava was deployed in 4 camps. Quickly prepared artillery posts allowed to begin bombardment of the fortress on 26 September in the evening. However, it did not bring expected results. All damages to the walls were immediately repaired by the Moldavians. Additionally, defenders were also equipped with artillery and were responding with fire. A cannonball fired from a cannon at a castle killed a horse under one of the mercenaries,

Johann von Tieffen did not allow him to participate in the expedition, so he returned to Lviv with the assist of dignitaries, and, possibly, a certain number of ordinary soldiers. Liborius Naker, a secretary of the Grand Master, records that 140 riders were sent to the king and with them there was a group of several commanders and important personalities mentioned by names. He also mentions the accompanying supply train. However, the number of infantry that eventually reached Moldavia is not known, Toeppen 1874, 306; O. Górka estimates that the Teutonic Order's detachment behind the Dniester was over 200 strong, Górka 1933, 12; Grabarczyk 2000, 248-250; Plewczyński 2002, 133; Grabarczyk 2010, 434.

8 Kromer 1857, 1330.

9 Kreutel 1978, 90.

10 Papée 1999, 130-131; Grabarczyk 2000, 250-251; Plewczyński 2002, 134.

11 Liske 1888, 267.

12 Chłapowski et al. 1992, 86. 


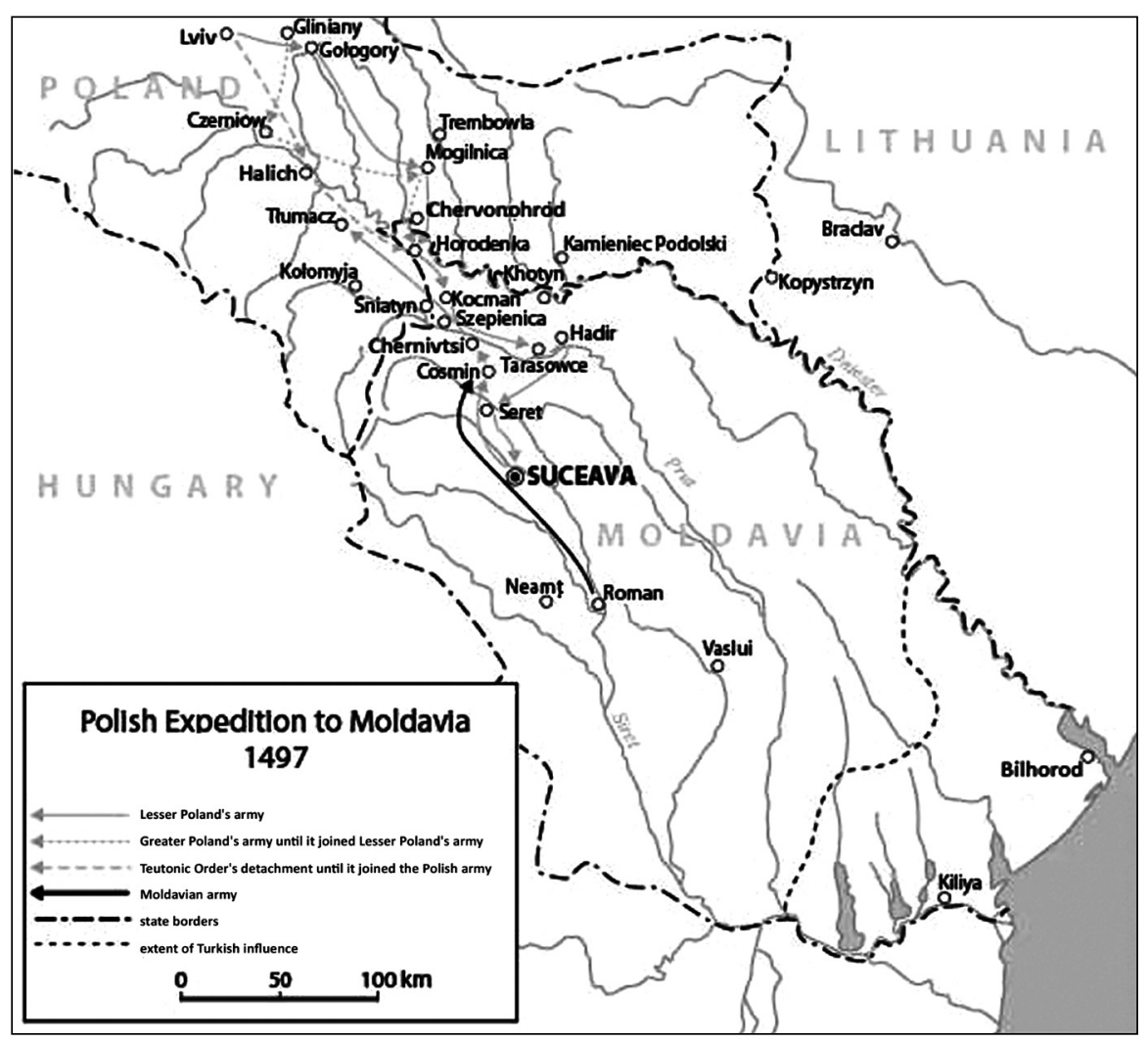

Fig. 1. Polish Expedition to Moldavia in 1497.

but the fate of the man is unknown ${ }^{13}$. It is unknown whether attackers confined themselves to artillery fire or any attempts at storming the fortress were undertaken.

The main problem for the Polish forces besieging the capital of Moldavia was the fact that it could not close the entire army of Stephen behind the walls. The hospodar prepared a fortress well for defense, and most of his army was deployed about $100 \mathrm{~km}$ southeast of it, near Roman. It should be noted that Stephen's army was a considerable force of 44,000 soldiers, including Turkish, Tatar, Wallachian and Hungarian detachments. Both the number and location of these troops greatly restricted the freedom of Polish actions around Suceava ${ }^{14}$.

The siege began to linger on, and therefore food and forage shortages were becoming increasingly common in John Albert's army. The army was cut off from the supplies from Ruthenia and was forced to search for supplies in the enemy territory. In the course of foraging, the Poles ventured into mountainous and forested areas, where they were attacked by Stephen's troops. One of such foraging detachments, which reached as far $100 \mathrm{~km}$ south of Suceava, was defeated near Neamţ $t^{15}$.

Food shortages and the lack of military success made the morale in the royal army deteriorate. Under such circumstances, Hungarian deputies arrived in Suceava on 12 October. At the meeting with John Albert, on behalf

13 AGAD, Oddział 85, t. 2, k. 86v 142, 143v

14 Górka 1938, 375; Plewczyński 2002, 140.

15 Bielski 1856, 908; Kromer 1868, 1329; Wapowski 1874, 27; Korzon 1912, 191. of Vladislaus Jagiellon they demanded the withdrawal of the Polish troops from Moldavia. In case of refusal, they threatened that the king of Hungary would personally go at the head of the army to support Hospodar Stephen. John I Albert, who already had a fever at that time, bent under pressure and commenced negotiations with the Moldavians. They concluded on 18 October with an agreement, by which the Polish army was to leave Moldavia, with a guarantee of a safe retreat.

The retreat of John I Albert's army started on October 19. The first units which were to go back were troops from Greater Poland. On the following day, the second unit with John Albert, the court banner and artillery set off. The third unit was composed of the knights from Lesser Poland, Ruthenia and Podolia, and the last one were mercenaries and the detachments sent by the Teutonic Order. On their way north the royal army began heavy plundering ${ }^{16}$.

The army divided into 4 parts reached an area near the village of Hlyboka on October 25. Great Poland's troops passed it and went on toward the town of Chernivtsi. After crossing a two-mile forest, they encamped near the village of Cosmin ${ }^{17}$. The king with the rest of the army stopped for the night at Hlyboka ${ }^{18}$. In the morning they broke the camp and proceeded along the road that was used the day before without any problems by the general levy from Greater Poland. There was no reason to expect an attack

16 Plewczyński 2002, 143; Kromer 1868, 1332.

17 Cosmin - at present Valija Kuzmina in Ukraine, Chernivtsi Oblast. Fischer 1902, 58; Plewczyński 2002, 145.

18 Plewczyński 2002, 144 - map. 
from Stephen's forces. This explains why the knights went without weapons, not keeping formations (armis depositis et solutis ordinibus). First, artillery and wagons (bombardis et impedimenta) entered a gorge. The ailing king followed them in a carriage, escorted by the court banner (curru a rotis pensili). Then, there followed the general levy detachments from Lesser Poland, Ruthenia and Podolia. The rear-guard were mercenaries along with the detachment of the Teutonic Knights ${ }^{19}$. Chroniclers agree that when the army reached the middle of the forest they were suddenly attacked by the Moldavians and their allies. The ambush was carefully prepared. Previously, the Moldavians undercut the trees and when the Poles appeared, the trees were overturned on them. This caused confusion and prevented any further movement along the road. Almost simultaneously, there was an attack of infantry from the flanks and of the Moldavian cavalry troops on the rear-guard. The rear-guard which consisted of the mercenaries and the Teutonic Knights did not manage to enter the gorge, at least not entirely, at the moment of attack $^{20}$. Being attacked from the flanks and from behind they found themselves in a very difficult position. Unprepared to fight, without orders, they had to fend off the attack planned by the enemies. The Polish troops which were in the gorge fought their way toward Cosmin. Among them was the court banner which managed to escort the king to safety. On the other hand, the troops who just began entering the gorge - including the mercenaries and the Teutonic Knights - turned south and were fending off the attack under the cover of wagons, in the same place where they spent the last night ${ }^{21}$. Having been separated from the rest of the army, they were in a desperate position. However, the court banner was sent to their rescue by the king after he had managed to get out of the gorge. The courtiers attacked the Moldavians unexpectedly and the enemies, challenged in the open space, were not able to repel the attack and rushed to escape. They were chased up to the River Seret, in which Jan Tęczynski, the courtiers' commander, lost his horse and was taken prisoner. Nevertheless, the attack of the courtiers should be considered successful as it saved the mercenaries from a total destruction.

19 Bielski 1856, 900; Kromer 1868, 1332; Wapowski 1874, 29; Fischer 1902, 56-57; Korzon 1912, 193; Plewczyński 2002, 145.

20 The army of John I Albert needed 6 hours to completely evacuate the camp, Fischer 1902, 56; Korzon 1912, 192.

${ }_{21}$ Poloni retrocedere et in castra, que adhuc immota erant currumque munitionem se recipere ceperunt, in quibus conferti ac conglobati inutiles sese ad defensionem effecerunt, alter alteri impedimento erat. Hostes undique instare, currus subvertere ceperunt; inclusi in desperacionem acti, opem de celo Jesum regem exclamando implorabant; tanto magis hostis urgebat, in extremo omnes versari periculo, venissentque haud dubie in gravius aliquod discrimen, ni Albertus rex ad famam hostilis perfide et quod iam in postremis pugnabatur, regium equitatum, florentem miliciam sub signis in subsidium laborantibus ex medio nemore submisisset, Wapowski 1874, 30.
After the battle, the scattered Polish troops gathered north of Cosmin forests, in a camp located probably near the village of Korowia, from where they set off to Chernivtsi on 27 October. The Poles were attacked by the Moldavians along the way. Finally, the royal army reached Tlumach, where on 5-7 November the troops were allowed to return home.

The register of horses and equipment lost by the courtiers has been unknown to scholars until now. This important source sheds some light on the participation of the court banner in the expedition to Moldavia, with special reference to the battle in the forests of Bukovina. The register includes the losses suffered during the entire campaign and consists of 125 items. Its author mainly recorded lost horses, giving - in most cases - the amount of compensation to which a soldier was entitled for a lost horse. 123 horses were lost, including: 11 horses died on the way, 112 horses lost in the battle, including 63 killed and 49 captured by the enemy. 4 records concerning horses are vaguely worded or unclear, and it is impossible to tell what happened to those horses. Among the lost horses were 29 large ones (so-called konie kopijnicze = equi hastarii) and 94 smaller ones (so-called konie strzelcze $=$ equi sagittarii) ${ }^{22}$.

Apart from the information concerning the loss of horses, the register also includes information about lost crossbows and armour and occasionally helmets. Compensation paid for large horses was in the amount of 18-20 florins, in one case it was 14 florins, for small horses - 10 florins, and for smallest ones -7 florins. Other data in the register of losses concerns weapons. The register shows that 81 crossbows were lost in the clash near Cosmin. The soldiers were given 30 groschen of compensation for one crossbow. Interestingly, the register mentions horsemen who lost more than one crossbow (in one case 2 crossbows and in the other one 3). In my opinion, this may mean that these combatants took part in several phases of the battle, complementing their equipment between those phases. In addition to crossbows, the register mentioned lost armours - 8 full armours and 69 light armours were recorded. A smaller amount of equipment lost by heavily armed combatants results from the fact that they were in a minority in the cavalry. The heavily armed warriors were on average $13 \%$ of the mercenary troops ${ }^{23}$.

The register also contains records of casualties. Such information appears as if in passing, together with the description of the circumstances of the loss of a horse and weapons. Interestingly, it is striking that more attention is paid to horses and equipment than to courtiers who were killed or taken prisoner.

As the author of the register focused on equipment, records concerning the horsemen are not always conclusive. I assumed that apart from a direct statement that

\footnotetext{
22 AGAD 134-142.

23 Grabarczyk 2015, 55-56.
} 
a horseman was killed or captured, also information that his horse was killed and his armour was lost was equivalent to the death of a given combatant, e.g., The horse was shot under the horseman on the battlefield, the armour was taken from him ${ }^{24}$. This assumption is supported by the notes which include the information that the horse and armour were lost but the horseman managed to survive, e.g., The horse [...] was captured in the battle and the horsemen escaped, the armour and two crossbows were left $t^{25}$. Counting this way, we receive the following result: 41 killed horsemen (the record in the source: the horse and the horseman were killed) and 12 probably killed (the record: the horse was killed, the armour was taken). Furthermore, the register informs of 31 horsemen who were taken prisoner (the record: the horse was captured with the soldier and the armour was captured). The number of courtiers who were taken prisoner can probably be enlarged by further 12 people - this is the number that appeared in the notes: the horse was captured and the armour was captured ${ }^{26}$. Information about the capture of a horse and an armour and sometimes also a crossbow by the enemy without mentioning that a horseman managed to escape, can be treated as synonymous with the fact that he was taken prisoner.

The court banner lost a total of 96 men in the battle of Cosmin. Unfortunately, without information on the actual size of the entire detachment it is impossible to determine the percentage of casualties.

Among the dead, only one horseman's name is known - Peter Wesel, a lancer. The losses of courtiers were greater than those of three mercenary detachment, for which analogical registers are available.

They inform us that 26-35 mercenaries were killed near Cosmin, and 17-20 were taken prisoner. Unfortunately, it is impossible to compare the percentages of losses.
However, in both formations more soldiers were killed than taken prisoner. Concerning the mercenaries, there was 1 soldier taken prisoner for 1.5 killed, while for the courtiers this proportion was $1: 1.2$.

Thanks to the register we also find out that the courtiers took part in the battle being divided into three detachments. The register recorded the names of their commanders: Hynek, Stanislaw Łącki (unfortunately, the third name is illegible $)^{27}$.

Histories of some of the participants in the battle which are included in the register of losses are exceptional for this period. Attention is drawn in particular to the unusual records which offer more details on what happened to the soldiers:

The horse was killed, the servant escaped, the armour disappeared

The horse was captured but the horseman Peter Wegierski escaped

The horse was captured in the battle, the armour and crossbow [were lost] and the servant lost one more crossbow

The horse survived but the servant was killed, the armour and crossbow were left there

The horse was injured under the horseman, the horsemen escaped without his armour. The horse died on the way

The horse was captured in the battle, the servant escaped with the armour and lost only the crossbow ${ }^{28}$.

The register of losses should be considered unusual and interesting source. It contains a number of valuable and unique pieces of information on the participation of the court banner in the battle of Cosmin. On the other hand, the information in the register should be compared with the data concerning the composition and size of this detachment in 1497. Unfortunately, due to the lack of research on the court banner in the Middle Ages, it is impossible to accomplish this task for the time being.

\section{Primary Sources}

AGAD. Archiwum Główne Akt Dawnych w Warszawie. Archiwum Skarbu Koronnego. Oddział 85. 2.

Kreutel R.F. (ed.) 1978. Aus der Chronik des Oruç. In: Der fromme Sultan Bayezid. Die Geschichte seiner Herrschaft (1481-1512) nach den altosmanischen Chroniken des Oruç und Anonymus Hanivaldus. Graz.

Bielski M. 1856. Kronika polska. Sanok.

Kromer M. 1868. Kronika polska. Sanok.

Liske X. (ed.) 1888. Memoriale Ordinis fratrum Minorum a Fr. Ioanne de Komorowo compilatum. In: Monumenta Poloniae Historica 5. Lwów.

\footnotetext{
${ }^{24}$ kuon byeli strzelczi [...] Nazad thensze kuon ustrzelon y zostal na placzu pod pacholkem zbroye strzelcze znego wzata.

25 kuon zvronaplesnywy strzelczy rowny thensze kuon wzat $w$ bitfie a pacholek ussedl se sbroya dwe kusse tam zostaty.

26 AGAD, 134-143.
}

\footnotetext{
27 czy czso sv byly z Laczskim v valnem hufie; Ci co byli z Hynkiem; czy su czso byli se panem [...] Stanislawem

${ }_{28}$ kuon zabit a pacholek vssedl ze zbroy tolko kussi zhynula; kuon wzat $w$ bitfie zbroye strzelcze kusse y kusse gyescze gyednv pacholek vpustyl; kuon zostal ale pacholek znego zbit y zostala tam strzelcze zbroye thasky a trzy kusse; kuon ranen pod samym wbitfie a Pyrsky se zbroy ussel ale asz $w d w u$ mylach zdechl rzecz yiest; kuon wzat w bitfie a pacholek ussedl se sbroya dwe kusse tam zostaty, AGAD, 135, 137, 142, 142v.
} 
Toeppen M. (ed.) 1874. Liborius Naker's Tagebuch über den Kriegszug des Hochmeisters Johann von Tieffen gegen die Türken im Jahre 1497. In: Scriptores Rerum Prussicarum 5. Leipzig.

Wapowski B. 1874. Kroniki Bernarda Bernarda Wapowskiego z Radochoniec, kantora krakowskiego, część ostatnia czasy podtugoszowe obejmujaca (1480-1535). In: Scriptores Rerum Polonicarum 2. Cracoviae.

\section{Literature}

Chłapowski K., Ciara S., Kądziela Ł., Nowakowski T., Opaliński E., Rutkowska G., Zielińska T. (eds.) 1992. Urzędnicy centralni i nadworni Polski XIV-XVIII wieku. Spisy. Kórnik.

Czamańska I. 1996. Mołdawia i Wołoszczyzna wobec Polski, Węier i Turcji w XIV i XV wieku. Poznań.

Fischer E. 1902. Kozmin zur Geschichte des polnisch-moldauischen Kriegs im Jahre 1497. „Jahrbuch des Bukowiner Landes-Museums" 10, 55-67.

Górka O. 1933. Białogród i Kilia a wyprawa z 1497 roku. „Sprawozdania z Posiedzeń Towarzystwa Naukowego Warszawskiego" 25 (3), 1-22.

Górka O. 1938. Nieznany żywot Bejazida II źródłem do wyprawy czarnomorskiej i najazdów Turków za Jana Olbrachta. „Kwartalnik Historyczny” 52, 375-427.

Grabarczyk T. 2010. Cosmin Forest, Battle of. In: C. J. Rogers (ed.), The Oxford Encyclopaedia of Medieval Warfare and Military Technology 1. New York, 434.

Grabarczyk T. 2000. Piechota zaciężna Królestwa Polskiego w XV wieku. Łódź.

Grabarczyk T. 2015. Jazda zaciężna Królestwa Polskiego w XV wieku. Łódź.

Korzon T. 1912. Dzieje wojen i wojskowości w Polsce. 1. Epoka przedrozbiorowa. Lwów.

Papée F. 1999. Jan Olbracht. Kraków.

Plewczyński M. 2002. Wojny Jagiellonów z wschodnimi i południowymi sąsiadami Królestwa Polskiego w XV wieku. Siedlce.

Smołucha J. 1997. Kilka uwag na temat wyprawy czarnomorskiej Jana Olbrachta w 1497. „Studia Historyczne” 40 (3) [158], 413-421.

Smołucha J. 1999. Papiestwo a Polska $w$ latach 1484-1526. Kontakty dyplomatyczne na tle zagrożenia tureckiego. Kraków.

\section{Streszczenie}

\section{Chorągiew nadworna w bitwie w Lasach Bukowińskich w 1497 r.}

Wyprawa Jana Olbrachta do Mołdawii w 1497 r. była jedną z największych operacji wojskowych, jaką przeprowadziło Królestwa Polskie w XV w. W źródłach mowa jest o armii liczącej 50-70 tysięcy ludzi. Było to głównie rycerstwo powołane pod broń w ramach pospolitego ruszenia, ponadto zaciężni, posiłkowy oddział krzyżacki oraz chorągiew nadworna (curienses). Jak się szacuje, ta ostatnia formacja liczyła wówczas ok. 2000 jeźdźców. Siły Jana Olbrachta wyruszyły ze Lwowa, by po długim marszu dotrzeć do Suczawy, stolicy hospodarstwa. Po zakończeniu nieudanego oblężenia wracająca do kraju armia, podczas przechodzenia przez Lasy Bukowińskie, została zaatakowana 26 października przez wojska hospodara Stefana Wielkiego. W tej bitwie ważną rolę odegrała chorągiew nadworna, która odparła nieprzyjaciół ratując armię jagiellońską przed zagładą. W Archiwum Akt Dawnych w Warszawie zachowały się rejestry koni i uzbrojenia utraconego przez curienses podczas kampanii mołdawskiej. Spis ten zawiera 125 pozycji, w których odnotowano stratę 123 koni, z czego 112 wierzchowców stracono w bitwie pod Koźminem. Ponadto w wykazie zanotowano stratę 81 kusz, 8 zbroi kopijniczych i 69 zbroi strzelczych. Rejestr zawiera również wzmianki o żołnierzach - poległych czy wziętych do niewoli. Zapiski te pojawiają się jednak okazjonalnie przy opisie utraconego ekwipunku i nie mogą służyć do stworzenia pełnej listy strat osobowych chorągwi nadwornej w bitwie w Lasach Bukowińskich, a tym bardziej - w całej kampanii mołdawskiej. 